\title{
Impact of quercetin on pulmonary toxicity induced by diesel exhaust nanoparticles in albino rat : Histological, immunohistochemical and biochemical study
}

\author{
Original Eman Mohamed Faruk', Sherifa Abd El Salam ${ }^{1}$, Samia Mahmoud Manawy², \\ Article Hanan Fouad ${ }^{3}$ \\ Departments of ${ }^{1}$ Histology and Cytology, ${ }^{2}$ Anatomy, Faculty of Medicine, Benha University, \\ Benha, ${ }^{3}$ Department of Medical Biochemistry, Faculty of Medicine, Cairo University, Cairo, \\ Egypt.
}

\begin{abstract}
Background: Diesel exhaust nanoparticles (DENPs) are one of the most prevalent environmental pollutants that adversely affect human health. DENPs are involved in the occurrence of chronic lung diseases such as COPD, bronchial asthma, chronic bronchitis and cancer.

Objective: Evaluation of DENPs damaging effects on the pulmonary tissue and assessment of the possible protective effects of Quercetin (QRT) on the lung tissue via histological, immunohistochemical and biochemical assessment.

Materials and Methods: Forty-five albino male rats were divided into 3 groups: Group I (control rats), Group II (DENPs group) received repeated doses of DENPs $(180 \mu \mathrm{g} / \mathrm{rat})$ intratracheally every other day for 6 days, Group III (DENPs + QRT) received quercetin orally $(60 \mathrm{mg} / \mathrm{kg}$ B.Wt.) $1 \mathrm{~h}$ before DENPs exposure. Examination of Lung tissues were conductedby histological and immunohistochemical techniques. Assessment of certain oxidative stress markers were also conducted.

Results: Group II showedsignificant changes in the histological picture of the lung tissue with collapsed alveoli, thick interalveolar septa and marked cellular infiltration. Collagen fibers were markedly increased by DENPs. Quercetin treatment led to amelioration of the histological findings in the lung tissue with marked decrease in collagen fibers. QRT led to significant decrease in iNOS immunoreactivity and increase in PCNA immunoreactivity.

Conclusion: Quercetin has protective effects against pulmonary toxicity induced by DENPs via its anti-inflammatory effects and anti-oxidant properties.
\end{abstract}

Key Words: Diesel exhaust nanoparticles, quercetin, pulmonary toxicity iNOS immunoreactivity, PCNA immunoreactivity.

Revised: 16 April 2019, Accepted: 15 May 2019.

Corresponding Author: Eman Faruk, Ph.D, Department of Histology and Cell Biology, Faculty of Medicine, Benha University, Benha, Egypt, Tel.: 01100057592,E-mail: Emanfaruk@researchu.edu, faruk_eman@yahoo.com

ISSN:2536-9172, June 2019, Vol. 3, No. 1

\section{INTRODUCTION}

Diesel exhaust emissions are one of the most prevalent environmental pollutants worldwide. A large number of toxicological studies showed that diesel engine emissions adversely affect human health. Thus, interests in studying molecular and cellular mechanisms causing these toxicological effects are mandatory. Diesel exhaust nanoparticles (DENPs) are involved in the development of chronic lung diseases such as COPD, bronchial asthma, chronic bronchitis ${ }^{[1]}$ as consequences of persistent oxidative stress, genotoxicity and chronic inflammation $^{[2-4]}$. DENPs are also associated with lung cancer $^{[5]}$, systemic complications such as cardiovascular diseases $^{[6]}$ and thrombosis ${ }^{[7]}$.

Quercetin is a polyphenol (flavonol: $\left(3,3^{\prime}, 4^{\prime}, 5,7\right.$ pentahydroxy-flavone) present in vegetables, nuts and fruit $^{[8,9]}$. Quercetin has several protective and therapeutic effects on human diseases due to its anti-inflammatory, antioxidative, antimicrobial, antiviral, and antiulcerogenic effects $^{[10,11]}$. Other studies reported that quercetin has also hypolipidemic, antiplatelet properties, antihypertensive, antineoplastic and antihepatotoxic ${ }^{[12]}$.Quercetin inhibits cyclooxygenase and lipoxygenase pathways at high doses, whereas at lower doses the lipoxygenase pathway is the main target of quercetin anti-inflammatory activities ${ }^{[13]}$.

The present study was conducted to evaluate DENPs damaging effects on the pulmonary tissue and to evaluate the possible protective effects of quercetin on the lung tissue via histological, immunohistochemical assess mentandanti-oxidant enzymes markers.

\section{MATERIALS AND METHODS}

\section{Reagents}

1- DENPS

DEHP, di(2-ethylhexyl) phthalate, (CAS no 204211-0, purity 99\%, lot $101 \mathrm{~K} 3696$ ) was purchased from Sigma Aldrich (St Louis, MO) dissolved in $0.5 \%$ DMSO 
(Sigma-Aldrich ${ }^{\circledR}$, St Louis, MO) for $6,12,24$ or $48 \mathrm{~h}$. Collection of DENPs were done by operating petroleum engines andmulticylinder diesel at $1500 \mathrm{rpm}$ speed according to a previous mentioned method ${ }^{[14]}$. Sterile normal saline containing Tween-80 $(0.01 \%)$ was used to make suspension of DENPs, control group received the same vehicle (normal saline with tween-80). The size of collected particles was less than $2.5 \mu \mathrm{m}$. The presence of nano-particles and morphological analysis were assessed by Transmission Electron Microscope (HR-TEM) (JEOL 3010).

\section{Quercetin (Sigma Aldrich, Egypt)}

Quercetin was dissolved in olive oil at a concentration of $60 \mathrm{mg} / \mathrm{kg} \mathrm{B}$.Wt and was delivered to rats by oral gavage $1 \mathrm{~h}$ before instillation of DENPs [10].Quercetin was found to be well tolerated in humans and animals in the given doses ${ }^{[15]}$.

\section{Animals and groups}

Forty-five albino male rats (220-260 g B.Wt.) were obtained from an inbred colony in Benha Universityexperimental animal unitinFaculty of Veterinary Medicine.Acclimatization for 7dayswas allowed before beginning of the experiment. Animals were kept at stabletemperature $\left(22 \pm 2^{\circ} \mathrm{C}\right)$ and controlled humidity (60\%), with dark: light cycle every $12 \mathrm{hr}$ and unrestricted feeding and drinking. They received a balanced diet. All animal procedures were performed in accordance with principles of Declaration of Helsinki (2008) and in accordance with the recommendations for the proper use and care of experimental animals. Institutional ethical committee of animalsreviewed andaccepted the protocol ofthe present study that was conducted in compliance with Institutional Animal Care Committee standard protocols.

Animals were randomly divided into the following groups:

- First group $(\mathrm{n}=15)$ : Animals were further subdivided into 2 subgroups: Subgroup IA $(\mathrm{n}=8)$ : Received normal saline with $0.01 \%$ tween 80 intratracheally as spray for 6 days intratracheally every two day ; Subgroup IB (n=7): Rats received a single dose of olive oil as a vehicle by oral gavage. All animals of these subgroups were sacrificed simultaneous with the corresponding experimental groups.

- Second group; (DENPs group, $\mathrm{n}=15$ ): Animals received intratracheal doses of DENPs repeated every two days $(180 \mu \mathrm{g} /$ rat $)$ for 6 days (16).

- Third group; (DENPs + Quercetin group, $\mathrm{n}=15$ ): Animals received oral quercetin $(60 \mathrm{mg} / \mathrm{kg} \mathrm{B}$. Wt. 1 hour before DENPs exposure (15). At the beginning of the experiment, sodium pentobarbital was injected for anesthesia intraperitoneal $(60 \mathrm{mg} / \mathrm{kg} \mathrm{b}$.wt). Insertion of 24-gauge cannula into the trachea was performed via the mouth. Suspension of DENPs and normal saline were instilled into the trachea by a sterile syringe. Administration was done on 1 st, 3rd and 5th days.

\section{Histological studies}

At the scheduled date of termination of the experiment, animals were exposed to ether inhalation as an anesthesia, sacrificed and lung tissuesweredivided and immediately fixed in 10\% formalin (neutral and buffered). Paraffin sections were stained with hematoxylin and eosin ( $\mathrm{H}$ and $\mathrm{E})$ to examinethe histological picture, Masson's trichrome was used to assess collagen subepithelial deposition $^{[17,18]}$.

\section{Immunohistochemistry study}

Immunohistochemical staining of inducible nitric oxide synthase (INOS) was conducted by using primary antibody of iNOS (rabbit polyclonal PA3-030A diluted 1:200, Thermo-Fisher Scientific).Secondary antibody used was rabbit antirat IgG Alexa Fluor-594 (diluted 1:200) from Thermo-Fisher Scientific ${ }^{c 19]}$. Immunohistochemical staining of anti-proliferating cell nuclear antigen (PCNA) was done by using primary monoclonal antibody anti-PCNA IgG antibody (Santa Cruz, CA, USA. Cat No.PCNA Antibody (PC11): sc-53407). The cellular site of the reaction was nuclear and brown color ${ }^{[20]}$.

\section{Morphometric study}

Measurement of alveolar wall thickness was done in H\&E stained sectioned and measurement of percentage of mean surface area of collagen fiber content was conducted in Masson's trichrome-stained sections withx 400 magnification. Optical density of positive immunoreactivity for iNOS and PCNA expressionwas done. Measurement of alveolar thickness, quantification of pneumocytes count were done in 10 images for each animal group using the Image Pro-Plus software version 16 (Media Cybernetics Inc. Bethesda, USA).

\section{Biochemical estimation of oxidative enzymes:}

\section{Homogenate preparation}

The saline washed lungs tissues were placed into tubes, frozen with liquid nitrogen and stored at $-70{ }^{\circ} \mathrm{C}$. Homogenization of the lung tissue was carried on by HeidolphDiax 900 homogenizer (HeidolphElektro GmbH, Germany) in chilled phosphate-buffer $(0.1 \mathrm{M}$ and $\mathrm{pH} 7.4)$ with dissolved $\mathrm{KCl}(1.17 \%)$, then centrifugationat $4{ }^{\circ} \mathrm{C}$ with $3000 \mathrm{xg}$ for $15 \mathrm{~min}$. The 
supernatant obtained was used for the downstream biochemical assays.

\section{Antioxidants: Catalase and superoxide dismutase enzymes and glutathione:}

\section{Determination of glutathione (GSH)}

Glutathione in the supernatant was determined by colorimetric detection kit (ThermoFisher Scientific, Cat. No.EIAGSHC) according to manufacturer's recommendations. Results of the GSH were measured innmol/mg tissue ${ }^{[21]}$.

\section{Superoxide dismutase (SOD) and Catalase (CAT) assay}

Commercial kits were used to assess SOD and CAT in stomach tissue according tomanufacturer's recommendations (Thermofisher scientific, Cat No. EIASODC for SOD and Cat. No. EIACATC for CAT). Results were exhibitedinmilli-mole/ minute/ milligram $(\mathrm{mmol} / \mathrm{min} / \mathrm{mg} \text { tissue })^{[22]}$.

\section{Statistical analysis}

Mean \pm SD was used for quantitative data. One-way analysis of variance (ANOVA)was used for multiplecomparisons to assessthe significance between different groups. Results were considered statistically significant for $p<0.05$.

\section{RESULTS}

\section{Results of Hematoxylin \& Eosin (H\&E):}

Histological picture of lung sections from control animals (group I) showed normal lung structure. Normal bronchioles and blood vessels were found between lung alveoli which have thin interalveolar septa (Fig. 1a, 1b). The lung alveoli of group II (DENP treated group) showed thick interalveolar septa with cellular infiltration, extravasated red blood cells (RBCs) (Fig. 1c). In group III (DENP and quercetin treated) lung sections showed alveoli, bronchioles with thin interalveolar septa. Extravasated $\mathrm{RBCs}$ and cellular infiltration were also detected (Fig. 1d).

\section{Masson's trichrome stain results:}

Group I (control) showed that the interalveolar septa have little amount of collagen fibers around blood vessels and bronchioles (Fig 2a). Sections of group II (DENPs) showed large accumulation of collagen fibers around bronchioles and alveoli as well as in the interalveolar septa
(Fig 2b). Group III (quercetin + DENPs) showed moderate accumulation of collagen fibers within the interalveolar septa, around alveoliand bronchioles (Fig2c).

\section{Immunohistochemical stain of iNOS}

Lung sections of group I showed few positive iNOS immunoreactivity inside cytoplasm of bronchiolar epithelial cells and cells lining the alveoli (Fig 3a). Sectionsin group II showed marked positiveiNOSimmunoreactivity inside cytoplasm of bronchiolar epithelial cells and cells lining the alveoli (Fig 3b). Group III showed moderate positiveiNOS immunoreactivity inside cytoplasm of bronchioles and alveoli lining cells (Fig 3c).

\section{Immunohistochemical stain of PCNA}

Section in Lung of group I showed strong positive PCNA immunoreactivity within the nuclei of cells lining alveoli and of bronchiolar epithelium (Fig 4a). Section in lung of group II showed negativePCNA immunoreactivity within the nuclei of cells lining alveoli and nuclei of bronchiolar epithelium (Fig 4b). Group III showed moderate positivePCNA immunoreactivity within the nuclei of cells lining alveoli and bronchiole (Fig 4c).

\section{Morphometric results \\ Alveolar septal wall thickness}

In the DENPs exposure group the alveolar thickness was significantly increase $(p<0.001)$ as compared to control. Quercetin has no effect on alveolar wall thickness (Table 1).

\section{Mean area percentage of collagen fibers}

There were significant differences in both mean area percentages of collagen fibers in DENPs exposure group in comparison to control $(p<0.05)$. Quercetin exhibited significant decrease in collagen fibers in comparison to DENPs group but the levels are still higher than control. (Table 1).

\section{Optical density of INOS and PCNA immunostaining (table1)}

The mean area percentage of iNOS positive immunostaining was significantly elevated with the DENPs exposed group as compared to the control group $(p<0.01)$. Whereas, PCNA immunostaining was significantly decreased with DENPs exposed group $(p<0.01)$. Quercetin showed significant elevation of PCNA and significant decrease in iNOS immunostaining in comparison to DENPS group but iNOS and PCNA levels were not normalized when compared to the control group (Table 1). 


\section{Biochemical results of oxidative enzymes and GSH}

In DENPs exposure group (D), CAT, GSH and SOD levels were significantly decreased in comparison to control group. In quercetin treated group, their levels were significantly increased when compared to DENP treated group but not normalized as compared to control group. (Table 2).

Table 1: Alveolar wall thickness $(\mu \mathrm{m})$, Mean area percentage of elastic and collagen fibers, Optical density of iNOS and PCNA in all groups

\begin{tabular}{|c|c|c|c|}
\hline $\begin{array}{l}\text { Group } \\
\text { Parameters }\end{array}$ & Control & $\begin{array}{c}\text { Group II } \\
\text { (DENPs; D) }\end{array}$ & $\begin{array}{c}\text { Group III (DENPs+quercetin; } \\
\text { D+Q) }\end{array}$ \\
\hline Alveolar wall thickness $(\mu \mathrm{m})$ & $2.61 \pm 1.51^{\mathrm{a}, \mathrm{b}}$ & $11.26 \pm 3.12^{*}$ & $9.89 \pm 3.50^{*}$ \\
\hline $\begin{array}{l}\text { Mean area percentage of } \\
\text { collagen fibers }\end{array}$ & $0.98 \pm 0.13 \mathrm{a}$ a b & $7.96 \pm 0.94^{*}$ & $5.03 \pm 2.40^{*} \mathrm{a}$ \\
\hline Optical density of iNOS & $12.21 \pm 2.29 \mathrm{a,b}$ & $53.44 \pm 8.23^{*}$ & $20.03 \pm 2.26^{* \mathrm{a}}$ \\
\hline Optical density of PCNA & $66.31 \pm 1.94^{\mathrm{a}, \mathrm{b}}$ & $13.44 \pm 10.53^{*}$ & $33.19 \pm 0.15^{* \mathrm{a}}$ \\
\hline
\end{tabular}

* Significant $p$ as compared with control normal group,a Significant $p$ as compared with D treated group and b Significant $p$ as compared with D + Q treated group.

Table 2: oxidative enzymes (CAT, GSH and SOD) in the lung tissues of all groups.

\begin{tabular}{|c|c|c|c|}
\hline Parameters & Group I Control & Group II (DENPs, D) & Group III (D+quercetin, $\mathrm{D}+\mathrm{Q})$ \\
\hline $\begin{array}{l}\text { Catalase activity }(\mathrm{CAT})(\mu \mathrm{mol} / \\
\mathrm{min} / \mathrm{mg} \text { protein) }\end{array}$ & $33.45 \pm 0.17$ & $20.12 \pm 0.99^{*}$ & $27.52 \pm 0.99^{* a}$ \\
\hline $\begin{array}{l}\text { Glutathione levels }(\mathrm{GSH}) \text { assay } \\
(\mu \mathrm{g} / \mathrm{mg} \text { protein) }\end{array}$ & $9.07 \pm 5.17$ & $3.09 \pm 1.93^{*}$ & $6.08 \pm 9.22^{* a}$ \\
\hline $\begin{array}{l}\text { Superoxide dismutase SOD } \\
\text { assay }(\mathrm{U} / \mathrm{mg} \text { protein }\end{array}$ & $70.98 \pm 2.19$ & $20.95 \pm 1.3^{*}$ & $40.03 \pm 1.52^{* a}$ \\
\hline
\end{tabular}

* Significant $p$ as compared with control normal group, a Significant $p$ as compared with D treated group and b Significant $p$ as compared with $\mathrm{D}+\mathrm{Q}$ treated group.

(A)
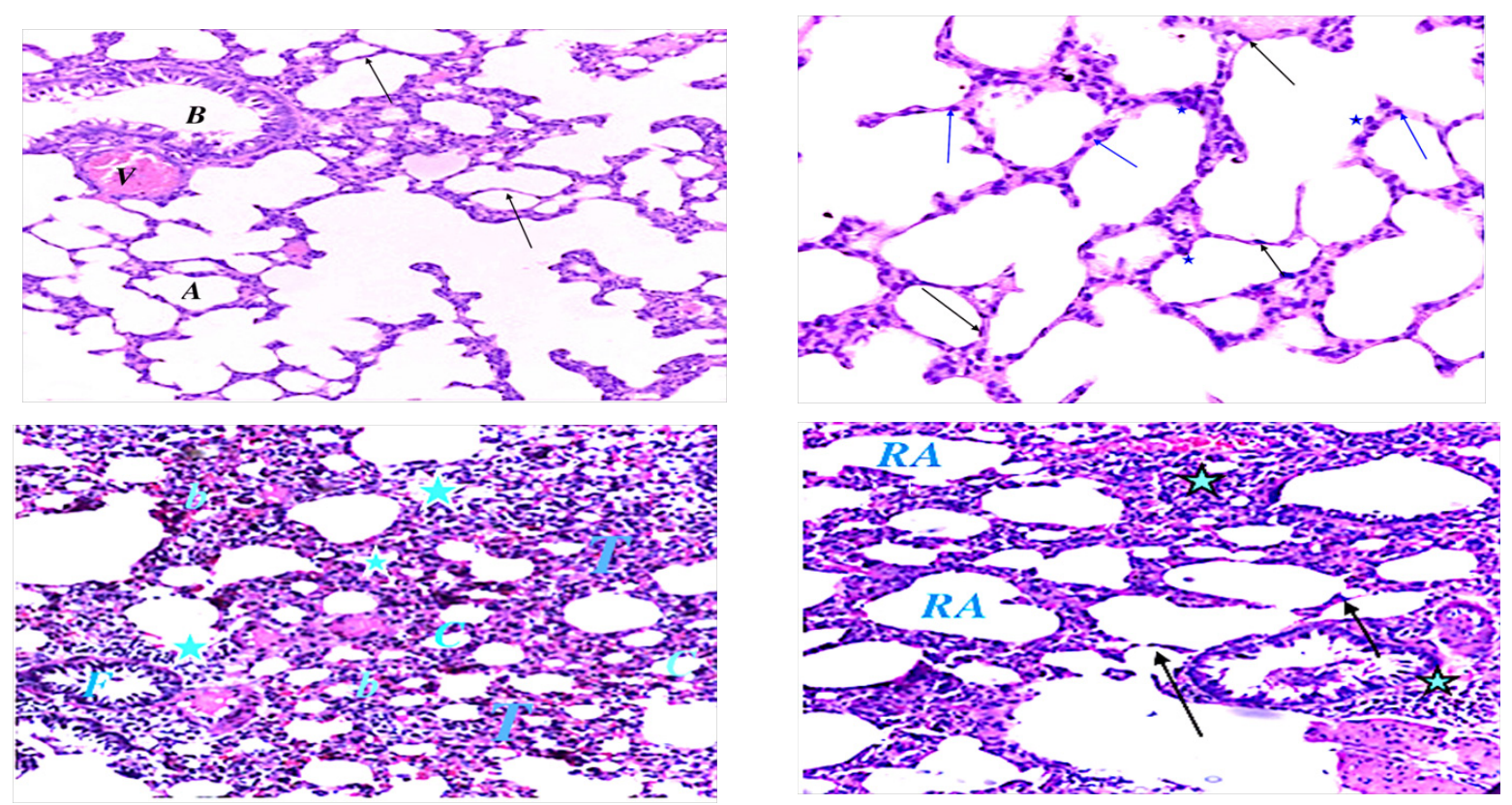

Fig. 1: (A)Photomicrograph of lung section of group I (control group) showing alveoli (A), bronchioles (B),thin interalveolar-septa (arrows) and a blood vessels (V)H\&E, 200.(B) a section in rat lung of group I (control group) showing pneumocyte type I(arrows), pneumocyte type II (lines) and alveolar macrophages (star), H\&E, 400.(C) The lung of group II (DENP treated group) showed some collapsed alveoli (c) with thick interalveolar septa (T), cellular infiltration around bronchiole and alveoli(stars), extravasated red blood cells (b) and exfoliated epithelial cells in the lumen of bronchiole (f). (D) Group III (quercetin treated group) showed apparently thin interalveolar septa (arrows) with some dilated ruptured alveoli (RA) and cellular infiltration (stars) H\&EX 200. 
(A)

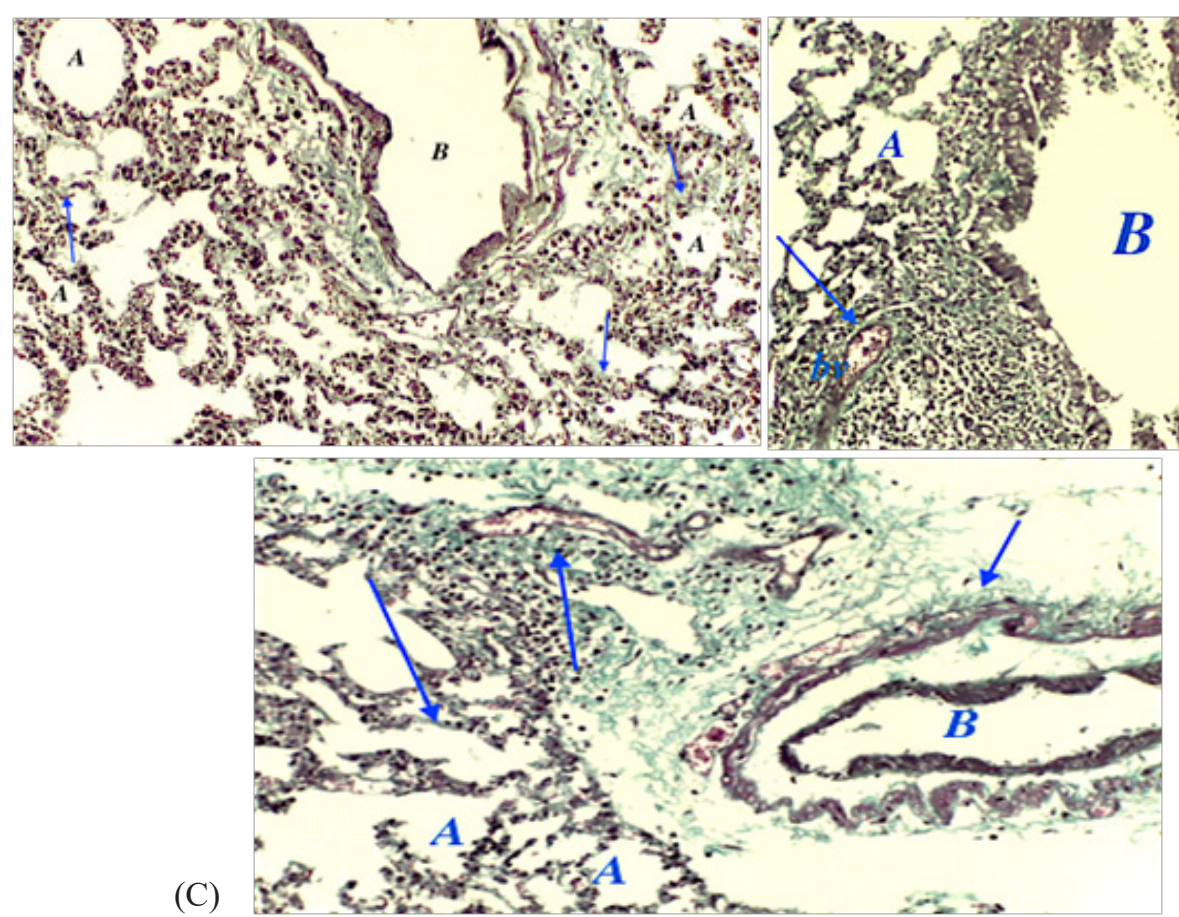

Fig 2: (A)Photomicrograph of lung sectionof Group I showedlittle amount of collagen fibers in inter-alveolar septa (arrow $\uparrow$ ) and around alveoli (A) (Masson's trichrome, X200). (B) Group II showing large accumulation of collagen fibers around bronchiole (B), around alveoli (A)andinside interalveolar septa (arrow $\uparrow$ ). Notice congested blood vessels (bv) (Masson's trichrome, X200).(C) Moderate accumulation of collagen fibers inside interalveolar septa (arrow $\uparrow$ ), around alveoli (A) and around thebronchioles (B) in group III (Masson's trichrome, X200).

(A)
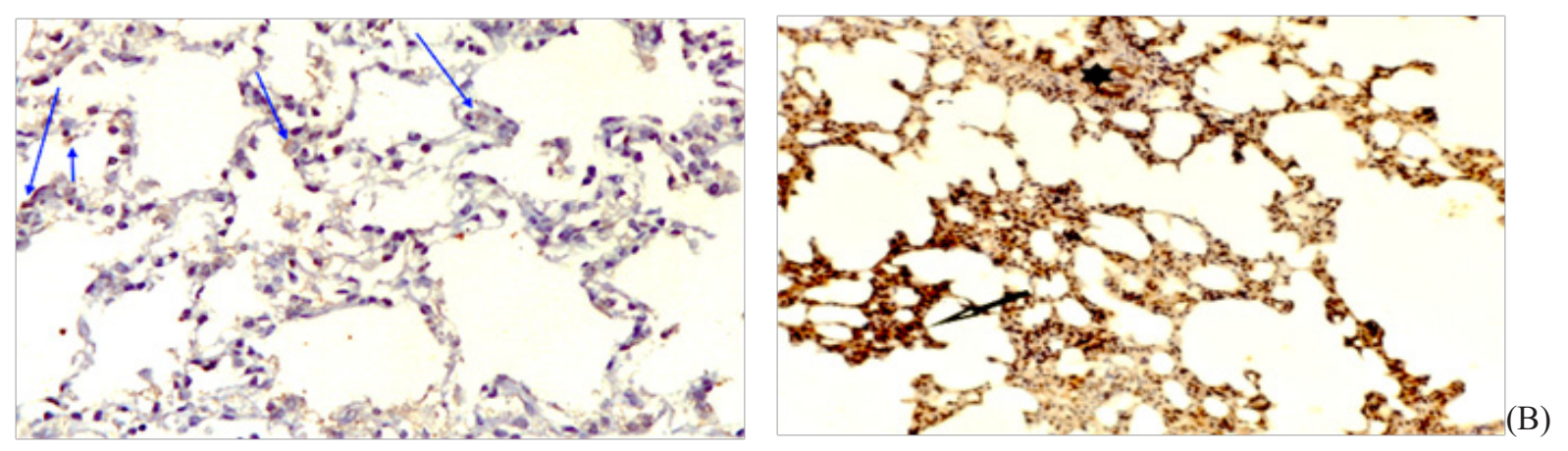

(C)

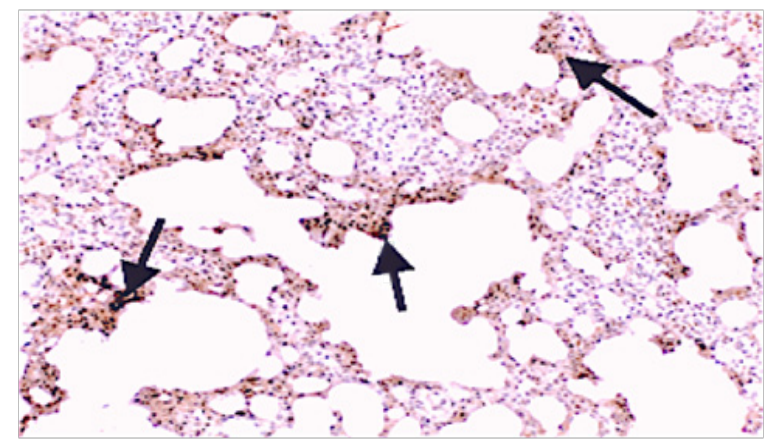

Fig. 3: (A)Photomicrograph of lung section of Group I showed few positive iNOS immunoreactivity (arrows) within the cytoplasm of alveolar cells. (B) Group II rat lung showing marked positive iNOS immunoreactivity in alveolar cells. (C) group III showing moderate positive iNOS immunoreactivity in alveolar cells.(Immunostaining for Inos X200). 


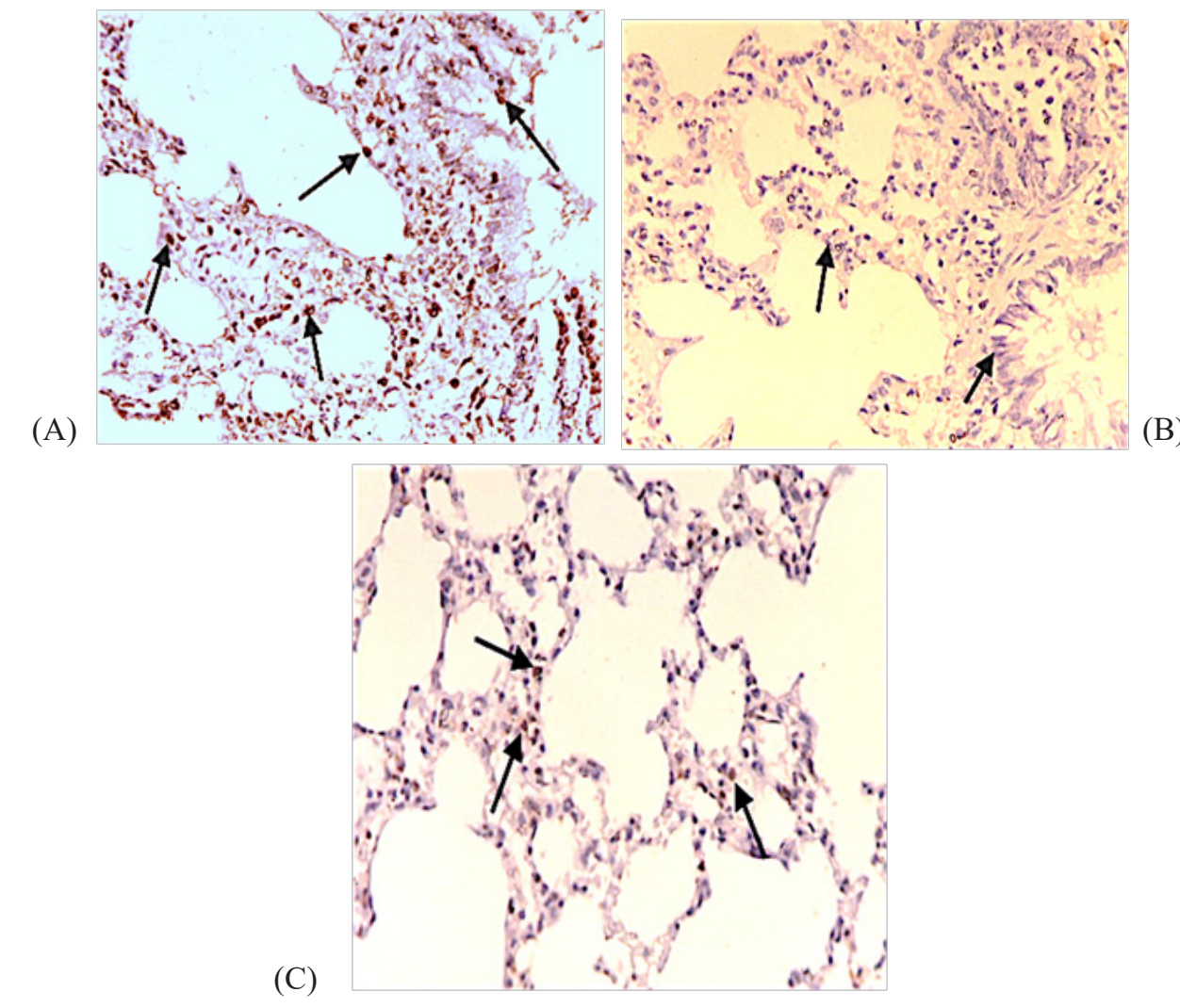

Fig 4: (A) A photomicrograph of a section in rat lung of Group I showing marked positive PCNA immunoreactivity (arrows) within the nuclei of alveolar cells. (B) Group II rat lung showing negative PCNA immunoreactivity in nuclei of alveolar cells.(C) group III showing mild positive PCNA immunoreactivity in nuclei of alveolar cells.

(Immunostaining for PCNA X200).

\section{DISCUSSION}

The current study was performed to assess the potential of protective effects of quercetin on DENPs-induced lung damage and toxicity with mechanistic focus on oxidative stress, inflammation, fibrosis and cell proliferation. Results of the present study showed significant changes in the histological picture of the lung tissue with collapsed alveoli, thick interalveolar septa and marked cellular infiltration. Collagen fibers were markedly increased by DENPs. Quercetin treatment led to amelioration of the histological findings in the lung picture with marked decrease in collagen fibers. Terzano et al. ${ }^{[23]}$ reported similar findings. They stated that the inhaled nanoparticles of fuel exhaust cause chronic inflammation due to the cyclic redox reactions with generation of reactive oxygen species. Phagocytosis of the alveolar macrophages is adversely inhibited by DENPs. DENPs are involved in the development of chronic bronchitis, bronchial asthma and COPDand lung cancer ${ }^{[24]}$.

This is in agreement with theobservations of other investigators who have reported that exposure to DEPs induced significant cell inflammation and thickness of alveolar wall with blood congestion, all of which may be the reason for cellular toxicity ${ }^{[25]}$.

Other authors attributed the occurrence of bronco alveolar cell damage is due to theactivation of proinflammatory responses via differential pathways in human bronchial epithelial cells ${ }^{[26]}$.

Quercetin has significant anti-inflammatory effects and antioxidant properties with subsequent amelioration of DENPs-induced damage in different tissues ${ }^{[8,10]}$. Our findings agreed with results reported by Huang et al. ${ }^{[9]}$ who stated that quercetin attenuated lipopolysaccharideinduced pathological changes in the lung tissue where the inflammatory cell infiltration and alveolar wall thickening were attenuated by quercetin pretreatment.

In the present study, there was extensive collagen fibers around some Bronchiole andalveoli. The latter findings wereconfirmed by an increased area $\%$ of collagen fiberscompared with the control and quercetintherapy groups.

This has been confirmed by other researchers, 
who found that the bronchial, alveolar fibrosis and lymphocyticinfiltrates with polymorphonuclear leukocytes after theadministration of DENPs ${ }^{[27]}$. These data correspond with a previous study that demonstrated acute pulmonary injury and inflammation in normotensive and hypertensive rats following exposure to the gas-phase components of $\mathrm{DE}^{[28]}$

In the current study, the immunostaining for PCNA and iNOSwas positive in the alveolar and bronchiolar cells in the control group, while in the DENPs group the immunostaining for PCNA was negative and markedly positive of iNOS immunostaining in alveolar and bronchiolarcells.

As regards immunohistochemical assessment of iNOS, our results showed that quercetin treatment led to a moderate decrease in iNOS immunoreactivity and moderate increase in PCNA immunoreactivity in the lung tissue of DENPs exposed rat group. These observations could be explained by the study of Marija et al. ${ }^{[29]}$ who stated that induction of iNOS plays a major role in DENPs mediated lung toxicity. Jing et al. ${ }^{[0]}$ stated that quercetin causessignificant down-regulation of inducible nitric oxide synthase (iNOS) and nuclear factor kappa B pathway in human hepatocyte cell line and this may contribute to the anti-inflammatory effects of quercetin. On the other hand, Baltaci et al. ${ }^{[31]}$ and Bao et al. ${ }^{[32]}$ stated that quercetin has the ability to stimulate neuronal NOS and endothelial NOS with subsequent enhancement of the production of NO that would quench reactive oxygen species and inhibition of hyperproliferation of gastric mucosal cells in rats treated with chronic oral ethanol. Quercetin was reported to downregulate the expression levels of proliferating cell nuclear antigen (PCNA) $)^{[33,34]}$.

In addition, significant increase in PCNA immunoreactivity was detected in quercetin treated group and control group in relation to DENPs treatedgroup. These results were also recorded by previous investigators $^{[35]}$. It was reported that quercetin administration to mice with lung disease could reduce apoptosis and inhibit the production of pro-inflammatory cytokines.

The protective effect of the quercetin was suggested to be mediated as it is a powerful candidate against oxidative stress-induced organ damage ${ }^{[36]}$.

\section{CONCLUSION}

In conclusion, quercetin has significant protective effects against pulmonary toxicity induced by DENPs via its anti-inflammatory effects and anti-oxidant properties.

\section{CONFLICT OF INTEREST}

There are no conflicts of interest

\section{REFERENCES}

1. Hecker L, Vittal R, Jones $\mathrm{T}$, et al. NADPH oxidase- 4 mediates myofibroblast activation and fibrogenic responses to lung injury. Nat Med. 2009;15(9):1077-1081.

2. Steiner S, Bisig C, Petri-FinkA, Rothen-Rutishause B. Diesel exhaust: current knowledge of adverse effects and underlying cellular mechanisms. Arch Toxicol 2016; 90(7): 1541-1553. doi: $10.1007 / \mathrm{s} 00204-016-1736-5$

3. Yang IA, Relan V, Wright CM, Davidson MR, Sriram KB, Savarimuthu Francis SM, et al. Common pathogenic mechanisms and pathways in the development of COPD and lung cancer. Expert OpinTher Targets 2011;15(4):439-456. doi: $10.1517 / 14728222.2011 .555400$

4. Alexis NE, Carlsten C. Interplay of air pollution and asthma immunopathogenesis: a focused review of diesel exhaust and ozone. IntImmunopharmacol 2014;23(1):347-355. doi: 10.1016/j.intimp.2014.08.009

5. Silverman DT, Lubin JH, Blair AE, Vermeulen $\mathrm{R}$, Stewart PA, Schleiff PL, et al. The Diesel Exhaust in Miners Study (DEMS): a nested casecontrol study of lung cancer and diesel exhaust. J Natl Cancer Inst 2014;106(8)pii: dju205. doi: 10.1093/jnci/dju205

6. Miller M, McLean SG, Shaw CA, Duffin R, Lawal AO, Araujo JA, et al. Diesel exhaust particles impair vascular function and promote atherosclerosis through generation of oxidative stress. Atherosclerosis 2015;241(1): e137-e138. doi: 10.1016/j.atherosclerosis.2015.04.477

7. Carolina Vieirade Souza, Sergio MachadoCorrêa Polycyclic aromatic hydrocarbons in diesel emission, diesel fuel and lubricant oil. Fuel 2016; 185: 925 - 931. https://doi.org/10.1016/j. fuel.2016.08.054.

8. Durga M, Nathiya S, Devasena T. Protective role of fenugreek leaf extract and Quercetin against petrol exhaust nanoparticle induced lipid peroxidation and oxidative stress in rat erythrocytes in vitro. Asian J Pharm Clin Res 2015;8(1): 237-241.

9. Huang $\mathrm{R}$, Zhong $\mathrm{T}$, $\mathrm{Wu}$ H.Quercetin protects against lipopolysaccharide-induced acute lung injury in rats through suppression of inflammation and oxidative stress. Arch Med Sci 2015;11(2): 427-432. doi: 10.5114/aoms.2015.50975 
10. Faruk EM, El Mansy A, Alasmari WAM, Elshazly AME. The possible protective role of quercetin on induced cardiac Oxidative DNA Damage by repeated exposure to diesel exhaust nanoparticles in rats (a histological and immunohistochemical study). J HistolHistopathol 2018;5(2). doi: 10.7243/2055-091X-5-2.

11. Anand David AV, Arulmoli R, Parasuraman S. Overviews of biological importance of quercetin: A Bioactive Flavonoid. Pharmacogn Rev 2016; 10(20):84-89. doi: 10.4103/0973-7847.194044.

12. Hashemzaei M, Delarami Far A, Yari A, Heravi RE, Tabrizian K, Taghdisi SM, et al. Anticancer and apoptosis inducing effects of quercetin in vitro and in vivo.Oncol Rep 2017;38(2):819-828. doi: 10.3892/or.2017.5766

13. Doucet MS, Jougleux JL, Poirier SJ, Cormier $\mathrm{M}$, Léger JL, Surette ME, et al. Identification of Peracetylated Quercetin as a Selective 12-Lipoxygenase Pathway Inhibitor in Human Platelets. MolPharmacol 2019;95(1):139-150. doi: $10.1124 / \mathrm{mol} .118 .113480$

14. Durga M, Nathiya S, Rajasekar A, Devasena T. Effects of ultrafine petrol exhaust particles on cytotoxicity, oxidative stress generation, DNA damage and inflammation in human A549 lung cells and murine RAW 264.7 macrophages. Environ ToxicolPharmacol 2014;38(2):518-530. doi: $10.1016 /$ j.etap.2014.08.003

15. Andres S, Pevny S, Ziegenhagen R, Bakhiya N, Schäfer B, Hirsch-Ernst KI, et al. Safety Aspects of the Use of Quercetin as a Dietary Supplement. MolNutr Food Res 2018;62(1). doi: 10.1002/ mnfr.201700447

16. Nemmar A, Subramaniyan D and Ali BH. Protective Effect of Curcumin on Pulmonary and Cardiovascular Effects Induced by Repeated Exposure to Diesel Exhaust Particles in Mice. PLoS ONE 2012; 7: 1-9.

17. Bancroft J. D, Layton C. The Hematoxylin and eosin. In: Suvarna S. K, Layton C, Bancroft J. D, editors. Theory Practice of histological techniques. 7th ed. Ch. 10 and 11. Philadelphia: Churchill Livingstone of El Sevier; 2013. pp. 179-220. http://dx.doi.org/10.1016/b978-0-70204226-3.00010-x

18. Alturkistani HA, Tashkandi FM, Mohammedsaleh ZM. Histological Stains: A Literature Review and
Case Study. Glob J Health Sci. 2016; 8(3): 72-79. doi: $10.5539 /$ gjhs.v8n3p72.

19. Abdel-DayemMM, Hatem M, Elgendy MS "Histological and Immunohistochemical Study on Nitric Oxide Synthase and Effects of Angiotensin Receptor Blockade in Early Phase of Diabetes in Rat Kidney", British Journal of Medicine and Medical Research. 2014; 4 (17): 3317-3338.

20. Zhou H, Huang T, Xiong Y, Peng L, Wang R and Zhang GJ. The prognostic value of proliferating cell nuclear antigen expression in colorectal cancer: A meta-analysis. Medicine (Baltimore). 2018 Dec; 97(50):e13752. doi: 10.1097/ MD.0000000000013752.

21. Wu X, Huang Q, Xu N, Cai J,Luo D, Zhang Q, et al. Antioxidative and AntiInflammatory Effects of Water Extract of Acrostichumaureum Linn. against EthanolInduced Gastric Ulcer in Rats. Evid Based Complement Alternat Med 2018;3585394.doi: $10.1155 / 2018 / 3585394$

22. Atalay F, Odabasoglu F, Halici M, Cadirci E, Aydin O, Halici Z, et al. N-Acetyl Cysteine Has Both Gastro-Protective and Anti-Inflammatory Effects in Experimental Rat Models: Its GastroProtective Effect Is Related to Its In Vivo and In Vitro Antioxidant Properties. J Cell Biochem2016; 117:308-19. (PMID: 25941092) doi: $10.1002 /$ jcb.25193

23. Terzano C, Di Stefano F, Conti V, Graziani E, Petroianni A. Air pollution ultrafine particles: Toxicity beyond the lung. Eur Rev Med PharmacolSci 2010;14(10):809-21 (PMID: 21222367).

24. Panel Z W ,DabPaolo T, Pianosi M D,Karina A ,Keogh MDd et al. The Diagnostic Accuracy of Fractional Exhaled Nitric Oxide Testing in Asthma: A Systematic Review and Meta-analyses. Mayo Clinic Proceedings 2018; 93:(2) 191-198.

25. Marie C, Remy P, Casanova S, Dhawan A, Lazzaroni A, Guillard JC, et al. Impact of titanium dioxide nanoparticle dispersion state and dispersion method on their toxicity towards a549 lung cells and escherichia coli bacteria. J Translational Toxicology 2014; 1:10-20.

26. Totlandsdal AI, Cassee FR, Schwarze P, Refsnes M, Lag M. Diesel exhaust particles induce CYP1A1 and pro-inflammatory responses via differential 
pathways in human bronchial epithelial cells. Part FibreToxicol 2010;741.

27. Snow J, John I, Desinia B et al. Inhaled Diesel Emissions Generated with Cerium Oxide Nanoparticle Fuel Additive Induce Adverse Pulmonary and Systemic Effects Samantha TOXICOLOGICAL SCIENCES, 2014, Vol. 142, No. 2.

28. Kodavanti, U. P., Thomas, R. F., Ledbetter, A. D., Schladweiler, M. C., Bass, V., Krantz, Q. T., King, C., Nyska, A., Richards, J. E., Andrews, D., et al. Diesel exhaust induced pulmonary and cardiovascular impairment: The role of hypertension intervention. Toxicol. Appl. Pharmacol.2013, 268, 232-240.

29. MarijaL,Beara $\mathrm{N}$, SiminD,Pintac $\mathrm{T}$ et al. Antioxidant and anti-inflammatory activities of quercetin and its derivatives. Journal of Functional Foods 2018;40:68-75.

30. Jing L, Weibiao Z. Role of quercetin in the physicochemical properties, antioxidant and antiglycation activities of bread Journal of Functional Foods. 2018; 40: 299-306.

31. Baltaci BB, Uygur R, Caglar V, Aktas C, Aydin $\mathrm{M}$, Ozen OA. Protective effects of quercetin against arsenic-induced testicular damage in rats. Andrologia. 2016 Dec;48(10):1202-1213. doi: 10.1111/and.12561.

32. Bao D, Wang J, Pang X, Liu H. Protective effect of quercetin against Oxidative Stress-Induced Cytotoxicity in Rat Pheochromocytoma (PC12) Cells. Molecules. 2017; 22(7). pii: E1122. doi: 10.3390/molecules22071122.

33. Li C., Zhang W.J., Frei B. Quercetin inhibits LPSinduced adhesion molecule expression and oxidant production in human aortic endothelial cells by p38-mediated Nrf2 activation and antioxidant enzyme induction. Redox Biol. 2016; 9:104-113. doi: 10.1016/j.redox.2016.06.006.

34. Prasad C.S., Bala M. Exploring in silico affinity of flavonoids and tannins to human fibroblast growth factorinducible14 (Fn14), a member of TNF receptor super family. Bioinformation. 2013;9:633-638. doi: 10.6026/97320630009633.

35. Yang W.S., Jeong D., Yi Y.S., Lee B.H., Kim T.W., Htwe K.M., Kim Y.D., Yoon K.D., Hong S., Lee W.S., et al. Myrsineseguiniiethanolic extract and its active component quercetin inhibit macrophage activation and peritonitis induced by LPS by targeting to Syk/Src/IRAK1. J. Ethnopharmacol. 2014;151:1165-1174. doi: 10.1016/j.jep.2013.12.033.

36. Hatahet T., Morille M., Shamseddin A., AubertPouessel A., Devoisselle J.M., Begu S. Dermal quercetin lipid nanocapsules: Influence of the formulation on antioxidant activity and cellular protection against hydrogen peroxide. Int. J. Pharm. 2017;518:167-176. doi: 10.1016/j. ijpharm.2016.12.043. 


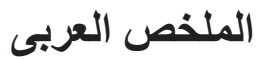

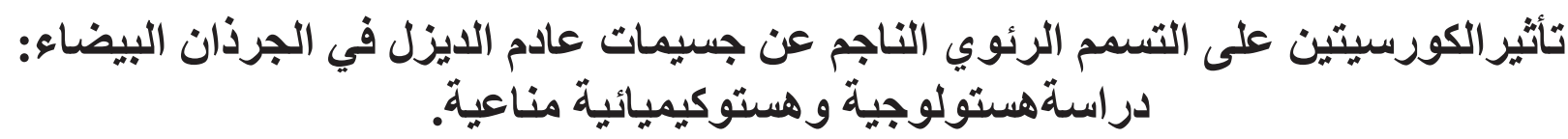

\author{
إيمان محمد فاروق 1، شريفه عبد السلام مرسىى1 ، سامية محمود مناوى2 ، حنان فؤاد33

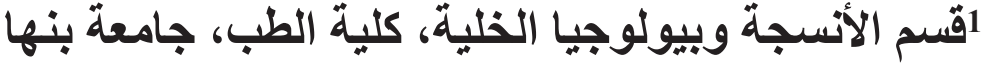 \\ 2قسم التشريح والأجنة، كلية الطب، جامعة بنها والئها \\ 3قسم الكيمياء الحيوية الطبية، كلية الطب، جامعة القاهرة
}

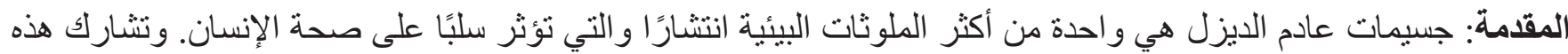

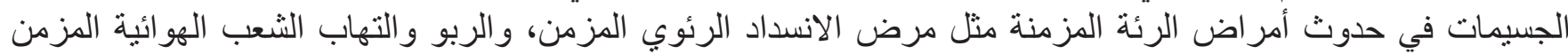
و والسرطان.

الهرف: تقييم الآثار الضارة الناجمة عن جسيمات عادم الديزل على الأنسجة الرئوية وتقييم الآثار الوقائية المحتملة للكورسيتين

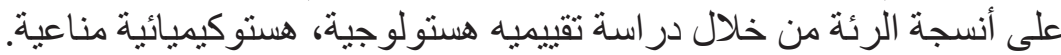

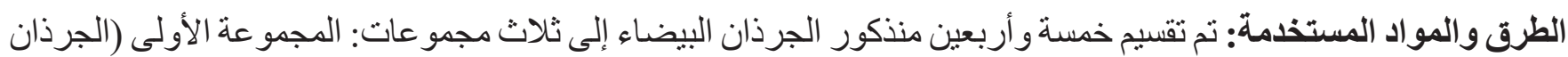

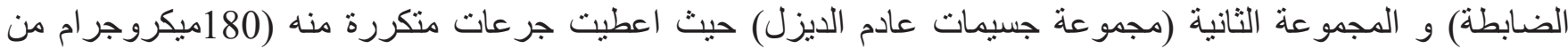

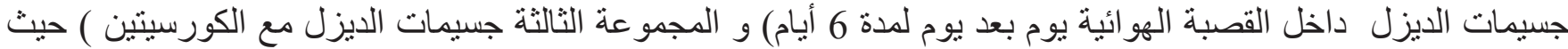

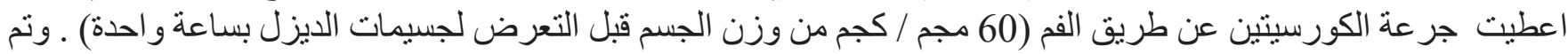

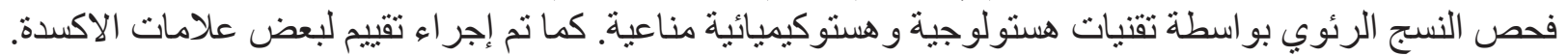

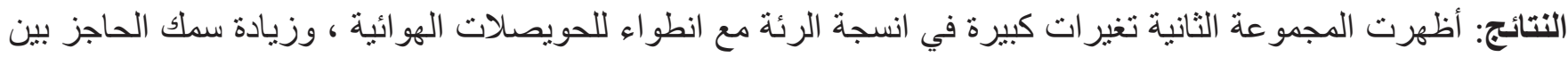

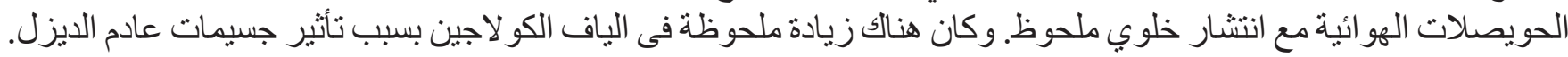

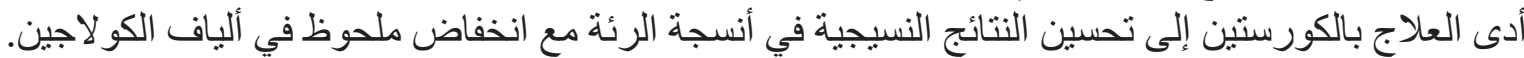

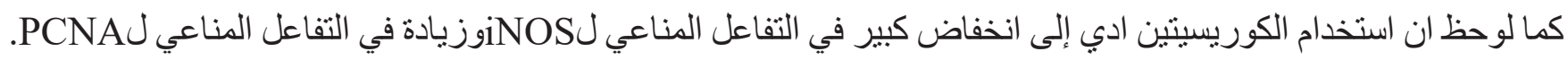
الاستنتاج: الكورسيتين له آثار وقائية ضد التسمم الرئوي الناجم عن جسيمات عادم الديزل عبر آثارئ آثاره المضادة للالتهابات وخصائصها المضادة للأكسدة. 